\title{
Investigation of Efficacy of Anti-Aging Liposomal Intimate Gel: An In Vivo Long-Term Study
}

\author{
Ivana Nešić, Vesna Savić, Ana Kolarević \\ University of Niš, Faculty of Medicine, Department of Pharmacy, Niš, Serbia
}

\begin{abstract}
SUMMAR Y
Liposomes have been used as universal carriers for decades, encapsulating many compounds with different cosmetic effects in order to achieve the quality, safety and efficacy of functional cosmetic products. In the present study, the efficacy of the application of the commercial liposome gel (SOPHY Anti-Aging Liposomal Intimate Gel), containing L-arginine, white curcuma extract, hyaluronic acid, lactic acid and vitamin $\mathrm{E}$ (previously shown to have various positive effects on the skin) as encapsulated cosmetic active ingredients, was examined in vivo on healthy volunteers. During a long-term 28-day study, biophysical skin parameters (skin humidity, TEWL, EI and $\mathrm{pH}$ ) were monitored. As a result, an increase in skin hydration, decrease in TEWL, and a slight decrease in EI and skin $\mathrm{pH}$ were observed. Thus, the examined cosmetic product has shown a positive effect on skin hydration, contributing to the renewal of skin barrier, also having the anti-irritating effects.
\end{abstract}

Key words: liposomal intimate gel, efficacy, in vivo study, biophysical skin parameters

Corresponding author:

Ivana Nešić

Email: ivana.nesic@medfak.ni.ac.rs 


\section{INTRODUCTION}

Liposomes are micro- or nano-size spheres made of one or more phospholipid layers surrounding an inner hydrophilic core filled with water. Liposomes have the ability to fuse the hydro-soluble substances into their interior and to fuse lipophilic and amphiphilic substances into phospholipid bilayers. Liposomes protect encapsulated substances from chemical and physical degradation and owing to their structure they also regulate the speed of the release and the localization of the released active substances into the biological system. Liposomes are biodegradable and biocompatible universal carriers, and their commercial application during the last thirty years confirms all their advantages over conventional medical and cosmetic products. A very good example is the application of liposomal products in dermal therapy and skin care, since liposomes themselves have positive effects on the skin regardless of the encapsulated active substances (phospholipids of the liposome membrane fuse into the stratum corneum creatinine, coat the skin surface, create the feeling of protective covering on the skin and reduce the trans-epidermal loss of humidity, thus strengthening barrier function of the skin) $(1,2)$.

Regulations prescribing the quality of the cosmetic products and raw materials for their production, including the conditions for the placement on the market of the Republic of Serbia, have to be harmonised with EU Regulation (EC) No. 1223/2009 on cosmetic products. Accordingly, the safety and the efficacy of the cosmetic products that will be placed on the Serbian market have to be proved.

Nowadays, the most significant testing of the cosmetic products' effects and some of their safety aspects are non-invasive in vivo tests on human volunteers based on the biophysical measurements on the healthy skin. Such measurements are taken in order to monitor changes in biophysical parameters directly linked with the structure and function of the skin before, during and after the application of the tested cosmetic product. The measurements are carried out with dedicated devices and under controlled conditions pursuant to the relevant instruction manuals $(3,4)$. In order to provide quality, safety and efficacy of functional cosmetic products, and also to meet the increased user demands, the cosmetic industry is focused on the development of new cosmetic active ingredients (CAI), their combination and encapsulation into convenient carriers.
Liposomes can be used for encapsulation of several CAI that show different cosmetic effects in order to achieve synergy in effects and stabilization (5).

Vitamin E (INCI-Tocopherol) belongs to liposoluble vitamins and has a significant role in skin protection against harmful effects of free radicals. This is a powerful antioxidant that effectively moisturizes the skin $(5,6)$. Curcumin (INCI) is also a strong antioxidant and prevents activation of transcriptional factors affecting the skin aging $(7,8)$. INCI-Hyaluronic acid is found in the dermis as a physiological molecule where it acts as a molecular sponge, links water and proteins, thus supporting the structural elements of the skin resulting in the desired full turgor (9). The application of $\alpha$-hydroxy acids (lactic acid) leads to loosening of connections between keratinocytes, which facilitates the desquamation of dead cells and thus signals faster recovery of the epidermis. These acids improve skin moisture and have a positive effect on its function as a barrier. There are certain findings which claim that they reduce the activity of the matrix metalloproteinase and slow down the degradation of collagen and elastin. There are many published papers that confirm that the effects of L-arginine are stimulation of blood circulation in the skin, improvement of the growth hormone effect, stimulation of fibroblasts and prevention of skin thinning. This substance also prevents free radicals from damaging DNA chains while extending the life of a cell $(10,11)$.

\section{A IMS}

The aim of this paper was to examine the efficacy of the application of the commercial liposomal gel (SOPHY Anti-Aging Liposomal Intimate Gel) containing L-arginine, white curcuma extract, hyaluronic acid, lactic acid, and vitamin E as encapsulated cosmetic active ingredients in in vivo test on the skin of healthy volunteers during 28 days of application.

\section{VOLUNTEERS AND METHODS}

\section{Volunteers}

The study was performed in accordance with the Declaration of Helsinki after obtaining a written informed consent from the volunteers. The study included 11 healthy volunteers without any history or clinical signs of dermatological disease. The volunteers were instructed not to use any skin care 
products one week before and throughout the study, but were allowed to wash normally during the study.

According to the published guidelines, the measurements were taken under controlled conditions: temperature $\left(21 \pm 1^{\circ} \mathrm{C}\right)$ and relative humidity $(40 \pm 5 \%)$, after 30 minutes of acclimatization period for the participants (12-15).

\section{Test sample}

SOPHY Anti-Aging Liposomal Intimate Gel is a commercial gel from the market produced by CureSupport, Netherlands for care and prevention of aging in the female intimate areas, i.e. for the prevention of the loss of elasticity and for suppressing the thinning of the skin of these areas. These effects are accomplished by stabilizing DNA in the skin cells and by stimulating microcirculation with antimicrobial effects. The gel contains L-arginine, turmeric, hyaluronic acid, lactic acid, and vitamin $\mathrm{E}$ encapsulated in liposomes. Ingredients (INCI) of the product: Aqua, Lecithin, Arginine, Glycerine, Tetrahydrodiferuloylmethane, Sodium hyaluronate, Lactic acid, Sodium benzoate, Potassium sorbate, Tocopherol.

\section{Testing protocol}

The study included 11 healthy female volunteers, aged 22-59 years (an average of 28.92 \pm 10.83 years). Volar parts of the forearms of 11 volunteers were treated with LG samples, in the area of the marked surface of $9 \mathrm{~cm}^{2}$ using a cardboard ruler with blank surfaces. On one forearm, one square was untreated, and was used as a control surface. After the initial measurement (before the start of the study, base values) the volunteers were instructed to apply samples (labelled with stickers, name and place of application) at home twice a day for 28 days, in the morning and evening after showering on areas of the marked surface using the previously mentioned cardboard ruler. Measurements were taken after 7, 14 and 28 days in the morning before the morning application of the samples. Also, measurements were taken two days after the last application.

In vivo measurements were performed using the Multi probe adapter 9 device, Courage \& Khazak Electronic $\mathrm{GmbH}$, Germany, and using the appropriate probes: skin capacitance was measured using Corneometar ${ }^{\circledR} \mathrm{CM} 820$ (measurements expressed in relative Corneometar units - RCU), transepidermal water loss (TEWL) using Tewameter ${ }^{\circledR}$ TM210, erythema index (EI) using Mexameter ${ }^{\circledR}$ MX18, and skin $\mathrm{pH}$ was measured using the skin $\mathrm{pH}$ meter ${ }^{\circledR 900}$.

\section{RESULTS AND DISCUSSION}

In vivo efficacy of application of Sophy Gel (containing L-arginine, white curcuma extract, hyaluronic acid, lactic acid, and vitamin $\mathrm{E}$ as encapsulated CAI) was examined by measuring the biophysical skin parameters on healthy volunteers during a longterm 28-day study.

\section{In vivo testing the effect of Sophy Anti-Aging Liposomal Gel on the skin humidity}

The results of the Sophy Gel effect on the healthy skin humidity are illustrated in Figure 1 . The results are the absolute values of the measured parameter during 28 days of application and 2 days after the application. During the entire period of application of the preparation (Sophy Gel), increased hydration of the skin was registered. The seven-day application led to increased skin humidity by $6.3 \%$, while after two- and three-week application, skin humidity was increased by $14.1 \%$ and $30.3 \%$, respectively. Maximum increase (33.5\%) was registered after four weeks of application. It was noticed that after three weeks of the Sophy Gel application, there was a slower increase of the skin hydration compared to the first three weeks of application (plateau formation), probably due to the established balance in the hydration of the skin surface layers and hydration potential of the applied preparation. It is obvious that the application of this preparation leads to the accumulation of the humidity in deep skin layers so that even after two days from the last application, skin humidity still remained at high level $(16.94 \%$ compared to the base value).

The favourable effect of liposomes on skin humidity was also registered in other research papers. It should be noted that sphingolipids, present in stratum corneum, and phospholipids, present in the deeper layers of the skin, are responsible for the humidity regulation. Akbarzadeh et al. concluded that the skin additionally acquired phospholipids using liposomes that penetrated into the stratum corneum and repeated liposome application resulted in the hydration of stratum corneum which is essential for the barrier function of the skin and its appearance and smoothness (12). Similar results were 
obtained by other researchers so that our results are in accordance with the data from available literature (13, 14). CAI encapsulated in liposomes (L-arginine, vitamin $\mathrm{E}$ and hyaluronic acid) also affect the level of skin hydration and thus contribute to the overall increase in its humidity. Results confirmed the thesis that the effect of the moisturization of the skin is not just a superficial action, but is often the consequence of functional changes in stratum corneum (15).

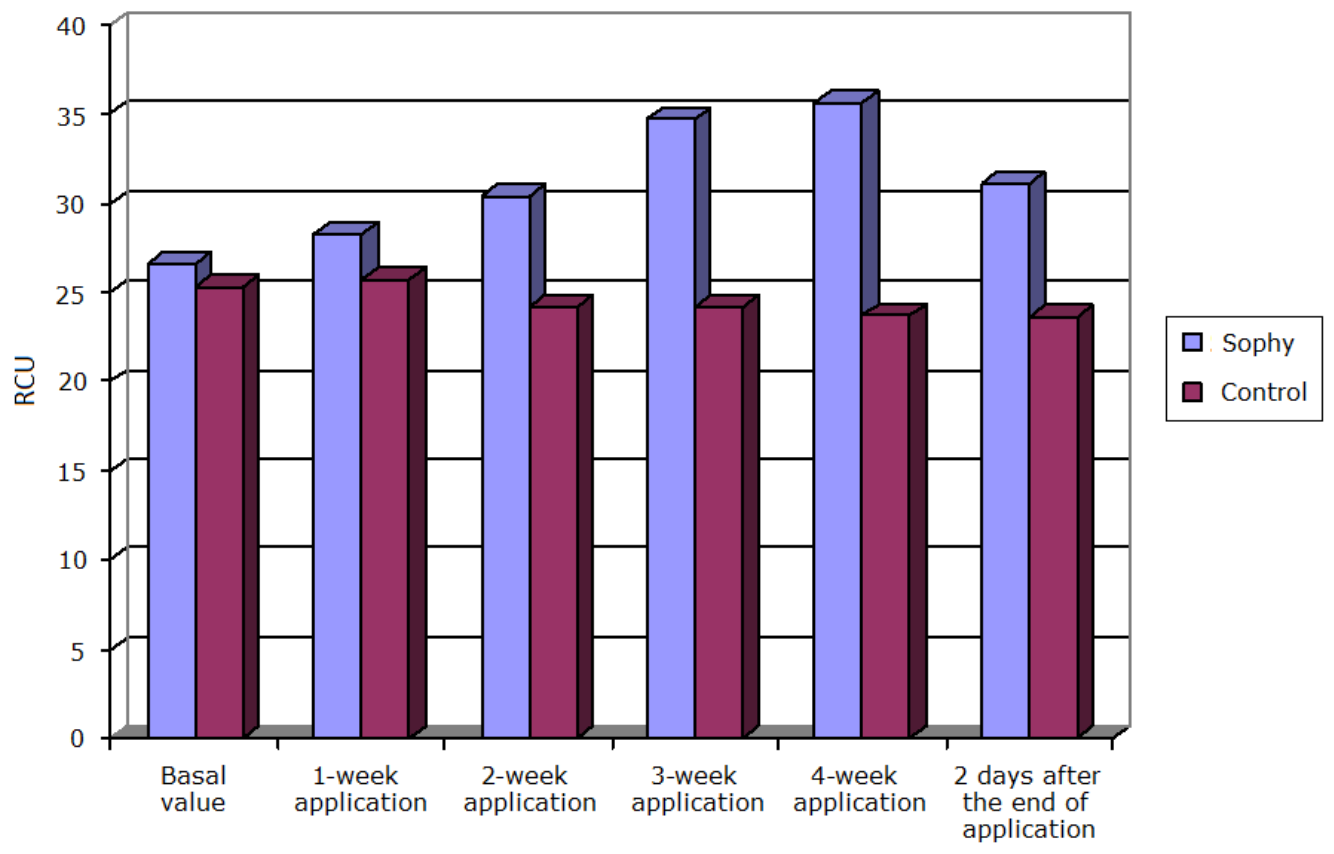

Figure 1. The effect of the Sophy Anti-Aging Liposomal Gel on the skin humidity (long-term test, application twice daily for four weeks)

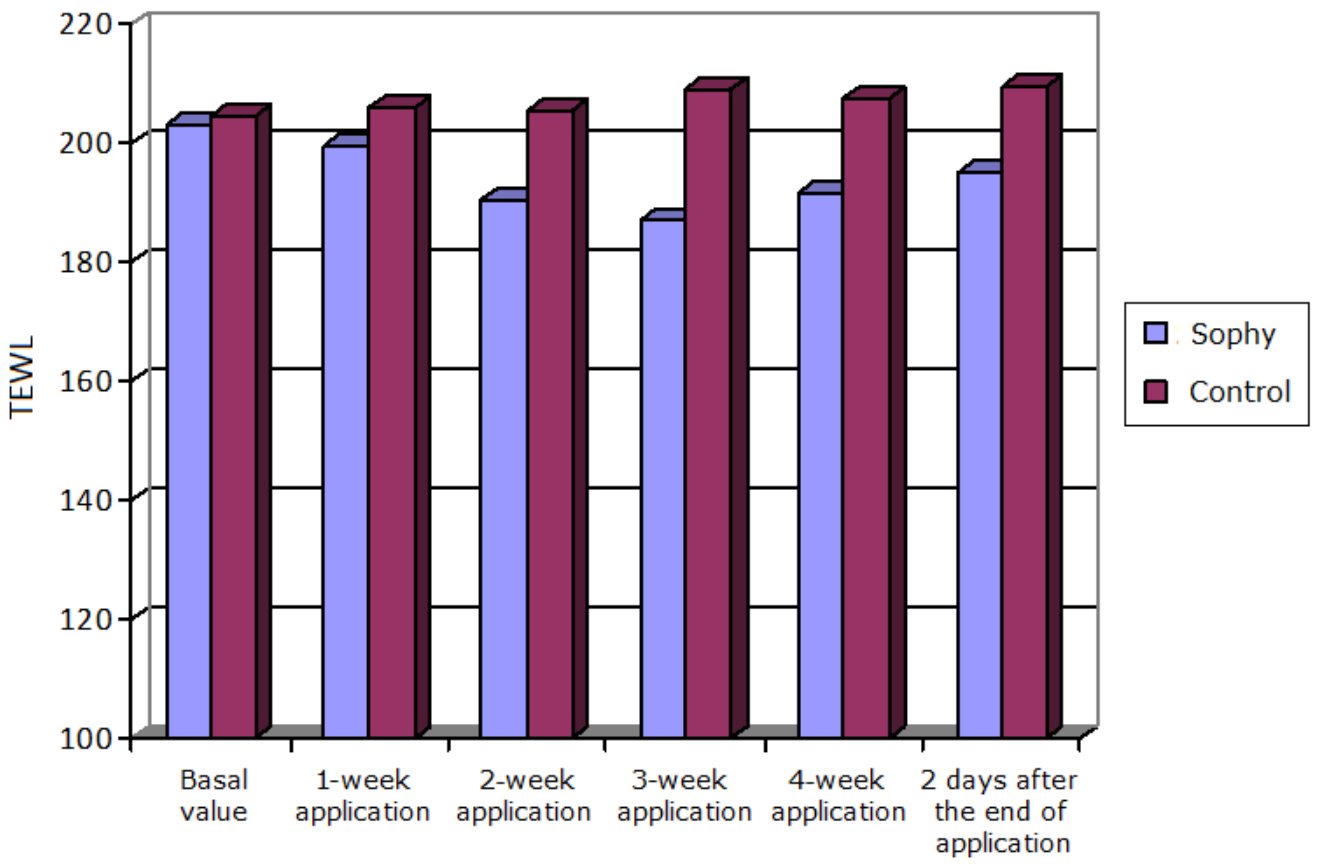

Figure 2. The effect of the Sophy Anti-Aging Liposomal Gel on TEWL (long-term test, application twice daily for four weeks) 
At the same time, the measurement of humidity on untreated skin pointed to the permanent decrease in its hydration (after four weeks there was a decrease in humidity in untreated skin in the amount of $11 \%$ ) which leads to the conclusion that the application of hydration preparations is necessary to maintain the optimum skin hydration.

\section{In vivo testing at the effect of Sophy Anti- Aging Liposomal Gel on TEWL}

TEWL represents imperceptible water release based on the passive diffusion in direction of concentration gradient from deeper, more hydrated skin layers (dermis, epidermis) toward the surface and through the surface of the skin into the external environment with the lower concentration of the humidity. Low values of this parameter are the main characteristic of the healthy skin and intact condition of its barrier (16). Therefore, TEWL is the most prominent in vivo indicator of the barrier function of the skin and its structural change $(17,18)$. Results regarding the effects of Sophy Gel on TEWL of participants' healthy skin are illustrated in Figure 2. The figure indicates that there was a notable gradual decrease in TEWL during the Sophy Gel application confirming the expected effects of the liposome preparations on the skin barrier features.

Liposome phospholipid coats the skin surface and fuses with the surface layers leading to decrease in water quantity that passes through these layers into the external environment. The lowest TEWL level in the period of the Sophy Gel application was measured after 28 days (a decrease of $29.4 \%$ compared to the base value). Even after this period, although the application of liposome preparation was ceased, a low TEWL value was registered. This contributes to the hypothesis that the application of liposome preparation leads to structural changes in deeper layers of the skin as a result of the incorporation of liposome phospholipid bilayers, so that these changes last longer and the skin keeps good barrier qualities for 48 hours after the application of the examined liposome preparation.

The positive effect on the skin barrier characteristics is a consequence of the presence of encapsulated CAI and their mutual effect with liposomes as their carriers. The consequence of TEWL reduction is reflected in the increased skin humidity registered in the study (Figure 1). Similar results demonstrating favourable effects of liposomal preparations on skin barrier characteristics have been reported in studies on healthy and irritated skin $(13,14)$. Regarding untreated skin during the first two weeks of testing, a TEWL increase was measured $(17.8 \%$ after the first and $27.19 \%$ after the second week), while after this period a TEWL decrease was registered, probably as a consequence of the water release from the deeper layers of the skin into the epidermis. All the time during the testing, the TEWL of untreated skin was higher than the TEWL at the beginning of the testing (base value). It was noticed that the increase of this parameter in the untreated skin was followed with a registered gradual reduction in hydration (Figure 1).

In vivo testing of the effect of Sophy AntiAging Liposomal Gel on EI

EI changes during the four-week application of the Sophy Gel (and two days after the end of application) on the healthy skin of participants is illustrated in Figure 3. During the entire measurement period (4 weeks of application and 2 days after the end of application) EI values were lower than initially, while the lowest EI value was registered after three weeks of Sophy Gel application (8.15 lower value compared to the base value) (Figure 3). The registered decrease of EI is probably a result of the presence of antioxydants (primarily vitamin $\mathrm{E}$ and white curcuma extract). The presence of the herbal antioxidants improves the anti-erythematous effect of cosmetic preparations, as stated in the literature (19).

The results of our study have shown that Sophy Gel could be applied to sensitive skin or skin reacting adversely (mostly by appearance of erythema) to the external environment factors. At all times of testing, measurements on the untreated skin recorded a mild increase in EI (maximum 2.35\%).

In vivo testing of the effect of Sophy AntiAging Liposomal Gel on the skin $\mathrm{pH}$

The application of the Sophy Gel twice a day during four weeks affected the skin $\mathrm{pH}$ value in such a way that the value of this parameter was gradually decreased as a result of the $\mathrm{pH}$ value of the preparation itself (Figure 4). The decrease in $\mathrm{pH}$ value of the skin surface can lead to its higher resistance against potential bacterial infections as it creates an unfavourable environment for their development. At the 


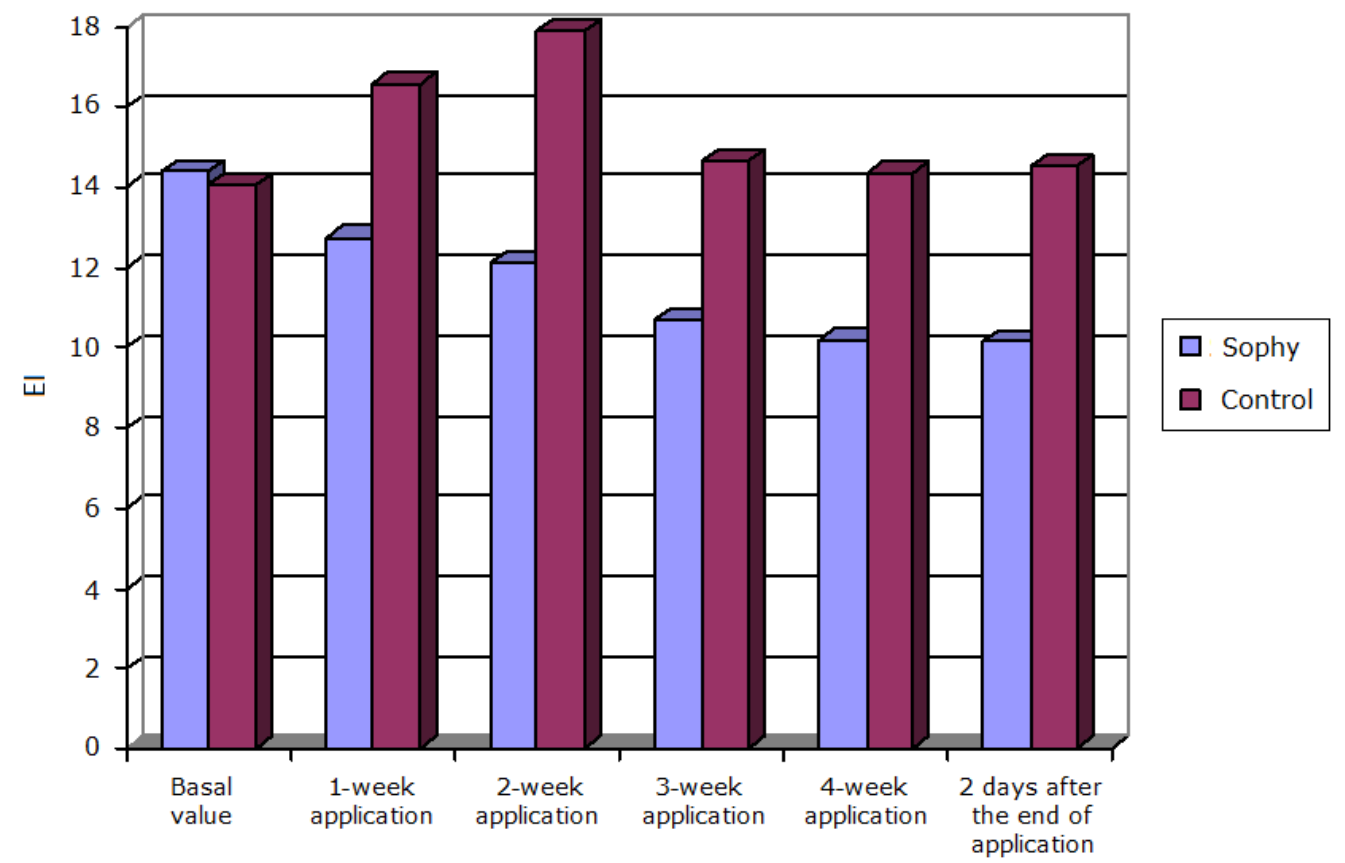

Figure 3. The effect of the Sophy Anti-Aging Liposomal Gel on EI (long-term test, application twice daily for four weeks)

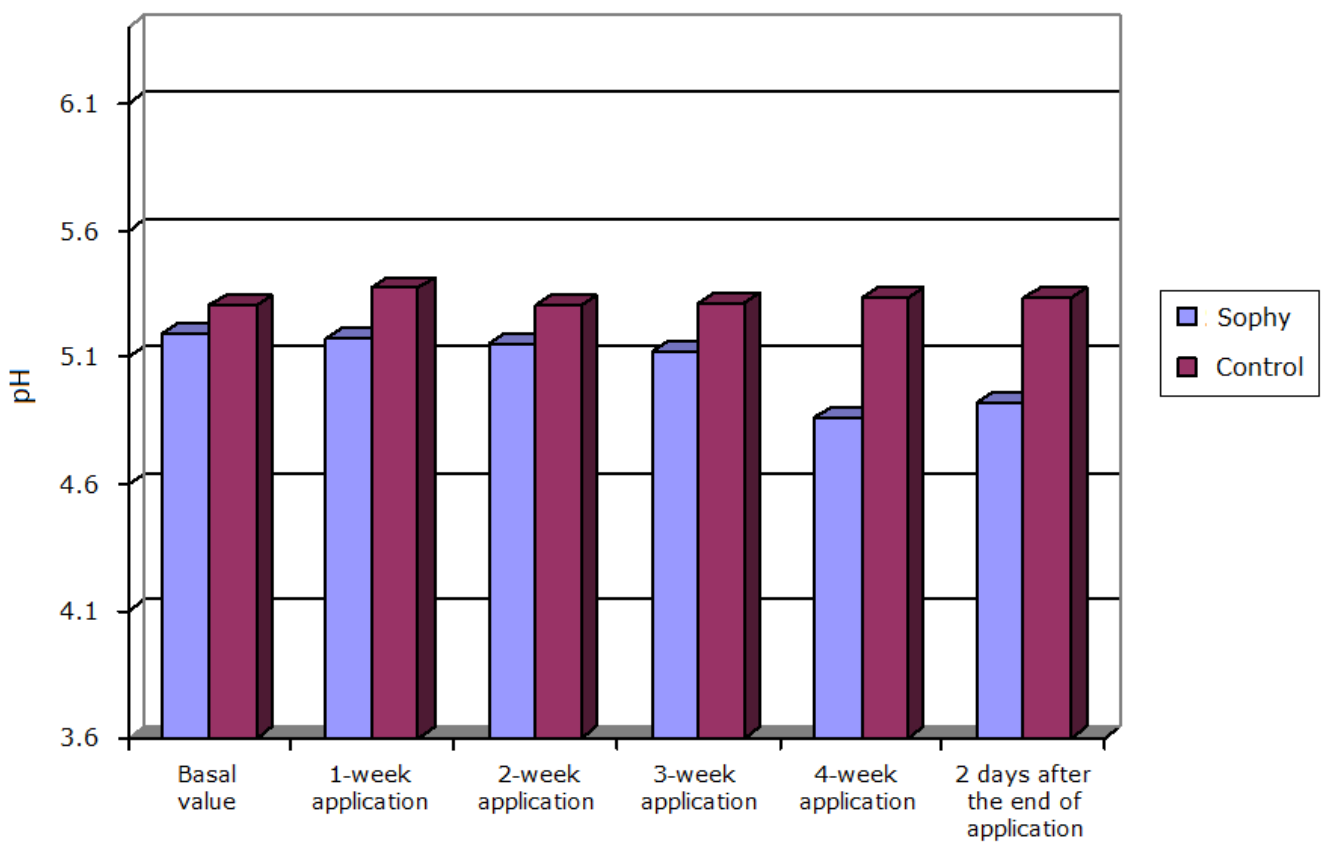

Figure 4. The effect of the Sophy Anti-Aging Liposomal Gel on the skin $\mathrm{pH}$ (long-term test, application twice daily for 4 weeks) 
same time, $\mathrm{pH}$ change was not registered on untreated skin.

\section{CONCLUSION}

The efficacy of the application of the commercial liposomal gel (SOPHY Anti-Aging Liposomal Intimate Gel), containing L-arginine, white curcuma extract, hyaluronic acid, lactic acid and vitamin $\mathrm{E}$ as encapsulated CAI, was tested in vivo on healthy volunteers during 28 days of application. It has been shown that during the application period, the examined cosmetic product has led to an increase in skin hydration, decrease in TEWL, and a slight decrease in EI and $\mathrm{pH}$ values of the skin. These effects are expected and are consistent with findings from the available literature dealing with the effects of the application of liposome and cosmetic active substances encapsulated in liposomes.

In accordance with the regulations governing the procedure for placing cosmetic products on the market, declarations/statements labeled to this product may be the following: positive effects on skin hydration; renewal of skin barrier features, and decrease in EI values.

\section{References}

1. R1. Rahimpour $Y$, Hamishehkar H. Liposomes in cosmeceutics. Expert Opin Drug Deliv 2012; 9(4): 443-55.

https://doi.org/10.1517/17425247.2012.666968

2. Bozzuto G, Molinari A. Liposomes as nanomedical devices. Int J Nanomedicine 2015; 10(1): 975-99.

https://doi.org/10.2147/IIN.S68861

3. Darlenski R, Sassning S, Tsankov N, Fluhr JW. Non-invasive in vivo methods for investigation of the skin barrier physical properties. Eur J Pharm Biopharm 2009; 72(2): 295-303. https://doi.org/10.1016/j.ejpb.2008.11.013

4. Piérard GE, Paquet P, Preudhomme L, Noël F, Quatresooz P. Skin bioengineering. Kanerva's Occupational Dermatology 2012; 991-1001. https://doi.org/10.1007/978-3-642-02035-3 88

5. Vuleta G, Savić S. Opravdanost primene vitamina i minerala u kozmetičkim proizvodima. Arh Farm 2009; 59(2-3): 212-25.
6. Packer L, Weber SU, Thiele JJ. Sebaceous gland secretion is a major physiologic route of vitamin $\mathrm{E}$ delivery to skin. J Invest Dermatol 1999; 113(6): 1006-10. https://doi.org/10.1046/j.1523-1747.1999.00794.x

7. Sekulović T, Vuleta G, Savić S. Efekti kozmetički aktivnih supstanci $\mathrm{u}$ tretiranju kože zahvaćene borama. Arh Farm 2012; 62(1): 22-37.

8. Alfa F, Mukhtar H. Photochemoprevention by botanical antioxidants. Skin Pharmacol Physiol 2002; 15(5): 297-306. https://doi.org/10.1159/000064533

9. Reuter H, Blatt T, Muhr GM, Stäb F. Cosmetics for the Elderly In: Barel A, Paye M, Maibach $\mathrm{H}$, editors. Handbook of Cosmetic Science and Tehnology, Edition IV.CRC Presss. New York, 2014; 501-5. https://doi.org/10.1201/b16716-48

10. Yamamoto $\mathrm{Y}$, Uede $\mathrm{K}$, Yonei N, et al. Effects of alpha-hydroxy acids on the human skin of Japanese subjects: the rationale for chemical 
peeling. J Dermatol 2006; 33(1): 16-22. https://doi.org/10.1111/j.1346-8138.2006.00003.x

11. Vasiljević D, Savić S, Đorđević Lj, Krajišnik D. Priručnik iz kozmetologije. Nauka, Beograd, II izdanje, 2009; 28-35.

12. Akbarzadeh A, Rezaei-Sadabady R, Davaran S, et al. Liposome: classification, preparation, and applications. Nanoscale Res Lett 2013; 8(1): 102-7. https://doi.org/10.1186/1556-276X-8-102

13. Arsić $\mathrm{I}$, Tadić $\mathrm{V}$, Vlaović $Đ$, et al. Preparation of novel apigenin-enriched, liposomal and nonliposomal, anti-inflammatory topical formulations as substitutes for corticosteroid therapy. Phytoth Res 2011; 25(2): 228-33.

https://onlinelibrary.wiley.com/doi/abs/10.1002/pt $\underline{\text { r.3245 }}$

14. Filipović M, Gledović A, Lukić M, et al. Alp Rose stem cells, olive oil squalene and a natural alkyl polyglucoside emulsifier: Are they appropriate ingredients of skin moisturizers-in vivo efficacy on normal and sodium lauryl sulfate-irritated skin Vojnosanit Pregl 2016; 73(11): 991-1002. https://doi.org/10.2298/VSP150116122F

15. Tasic-Kostov MZ, Reichl S, Lukic MZ, et al. Does lactobionic acid affect the colloidal structure and skin moisturizing potential of the alkyl polyglucoside-based emulsion systems Pharmazie 2011; 66(11): 862-70.

16. Fluhr JW, Darlenski R. Transepidermal Water Loss (TEWL), in Berardesca et al. (eds.), Non Invasive Diagnostic Techniques in Clinical Dermatology, Springer Berlin Heidelberg, 2014; pp. 353-6.

https://doi.org/10.1007/978-3-642-32109-2 32

17. Lodén M. Role of topical emollients and moisturizers in the treatment of dry skin barrier disorders. Am J Clin Dermatol 2003; 4(11): 771-88. https://doi.org/10.2165/00128071-200304110-00005

18. Buraczewska-Norin, Skin barrier responses to moisturizers: functional and biochemical changes. In: Lodén $\mathrm{M}$, Maibach $\mathrm{H}$, editors. Treatment of dry skin syndrome. Berlin: Springer Berlin Heidelberg; 2012; 525-44.

https://doi.org/10.1007/978-3-642-27606-4 37

19. Stojiljković D, Arsić I, Tadić V, et al. Standardized extract of wild apple fruit in alkylpolyglucoside-based cosmetic cream estimation of stability, safety, antioxidant activity and efficiency. Int J Cosmet Sci 2018; 40(3): 28594.

https://doi.org/10.1111/ics.12462 


\title{
Ispitivanje efikasnosti antiejdžing liposomskog gela: in vivo dugotrajna studija
}

\author{
Ivana Nešić, Vesna Savić, Ana Kolarević \\ Univerzitet u Nišu, Medicinski fakultet, Katedra Farmacija, Niš, Srbija
}

S A ŽETAK

Liposomi se već decenijama koriste kao univerzalni nosači, a koriste se i za inkapsulaciju mnogih jedinjenja sa različitim kozmetičkim efektima kako bi se postigli kvalitet, bezbednost i efikasnost funkcionalnih kozmetičkih proizvoda. U ovoj studiji, ispitivana je efikasnost primene komercijalnog liposomskog gela (SOPHY Anti-Age Liposomal Intimate Gel), koji sadrži L-arginin, ekstrakt bele kurkume, hijaluronsku kiselinu, mlečnu kiselinu i vitamin E (za koje je ranije pokazano da imaju različite pozitivne efekte na koži), kao inkapsulirane kozmetički aktivne sastojke, in vivo na zdravim dobrovoljcima. Tokom dugoročne dvadesetosmodnevne studije praćeni su biofizički parametri kože(vlažnost kože, TEGV, EI i pH). Kao rezultat, došlo je do povećanja hidratacije kože, smanjenja TEGV i blagog pada EI i pH kože. Dakle, ispitivani kozmetički proizvod ima pozitivan efekat na hidrataciju kože, doprinosi obnavljanju barijerne funkcije kože, a pokazuje i antiiritantne efekte.

Ključne reči: liposomski intimni gel, efikasnost, in vivo ispitivanje, biofizički parametri kože 